\title{
Determination of Mass Loss Rate and Smoke Generated of Jordanian Hardwood Timber under Different Flaming Combustion and Limited Ventilation Environment
}

\author{
AHMAD S. AWAD \\ Department of Mechanical Engineering, Faculty of Engineering Technology, Al-Balqa`Applied \\ University, Amman-JORDAN
}

\begin{abstract}
Natural wood has been used in structural applications for decades. Smoke from wood fires, additives and wood-protective coatings is a cause of serious injury in limited ventilation compartment. Ventilation restrictions in modern day designs complicate the combustion process and increase incomplete combustion products due to a reduction in the amount of oxygen available for fuel oxidation. Jordanian hardwood samples have been examined, tested and evaluated according to their mass loss rates, specific optical density, mass optical density, transmittance, and visibility using qualitative research used to realise the dynamics of fire phenomena. Four types of natural wood were tested under different heat fluxes with different Flaming combustion in a Smoke Density Chamber (SDC). The samples studied were Beech, Oak, Rhamnus, and Abies. The samples have been exposed to 25 and $50 \mathrm{~kW} / \mathrm{m}^{2}$ heat fluxes in a limited ventilation compartment. Twelve samples were tested, each with dimensions of $75 \times 75 \mathrm{~mm}$ and $10 \mathrm{~mm}$ thickness. An evaluation of the tested parameters, such as mass loss rate (MLR), specific optical density, transmittance, visibility and mass optical density (MOD have been carried out to determine their effectiveness as predictive parameters. Main results shows Beech has the lower values of specific optical density despite it has higher values of MLR\% and MOD compared to other samples studied. Also, the mass loss rate (MLR \%) increases with the heat flux even with different flaming conditions. In the opposite, there is a strong dependence for the mass optical density (MOD) on the heat flux and flaming conditions. Key conclusions have been drawn up that could be used in wood products and future works. The main objective of this work is to model the fire dynamic behavior in the pre-fire time. The results of this study can provide the bases for ventilation process and considerations of using natural woods in Jordan for different applications.
\end{abstract}

Key-Words: - Ventilation, Smoke, Burning Rate, Mass Loss Rate, Flaming Combustion, Specific Optical Density, Transmittance, Visibility, Mass Optical Density.

Received: January 5, 2020. Revised: May 26, 2020. Accepted: June 2, 2020. Published: June 8, 2020.

\section{Nomenclatures}

A Exposed Area of the Specimen $\left(\mathrm{m}^{2}\right)$

$\mathrm{A}_{\mathrm{F}} \quad$ The Fuel Surface Area $\left(\mathrm{m}^{2}\right)$

c $\quad$ Specific Heat $\left(\mathrm{J} / \mathrm{kg} .{ }^{\circ} \mathrm{C}\right)$

$\mathrm{D}_{\mathrm{L}} \quad$ Optical Density per Meter $\left(\mathrm{m}^{-1}\right)$

G Geometrical Factor for Chamber

I Light Intensity during the Test (cd)

$\mathrm{I}_{0} \quad$ Light Intensity before the Test (cd)

k Thermal Conductivity

L Optical Length of Smoke Measurement (m)

$L_{v} \quad$ Heat of Gasification $(\mathrm{kJ} / \mathrm{mol})$

$\mathrm{m} \quad$ Mass of the Specimen (gm).

$\dot{\mathrm{m}}$ " Burning Rate $(\mathrm{g} / \mathrm{s})$

$\dot{Q}^{\prime \prime}$ c Heat Release Rate $\left(\mathrm{kW} / \mathrm{m}^{2}\right)$

$\mathrm{S} \quad$ Visibility $(\mathrm{m})$

$\mathrm{D}_{\mathrm{s}} \quad$ Specific Optical Density

$\mathrm{t}$ Time (in Second)

T Transmittance

$t_{\text {chem }}$ Time required for the Mixture to Ignite (in
Second)

$t_{\text {mix }}$ Diffusion Time Required to Reach the Pilot (in Second)

$t_{p y}$ Time for the Solid to Attain Pyrolysis (in Second)

$\mathrm{V}$ Total Volume of the Chamber $\left(\mathrm{m}^{3}\right)$

$\alpha \quad$ Thermal Diffusivity (in $\mathrm{m}^{2} / \mathrm{s}$ )

$\Delta \mathrm{Hc}$ Heat of Combustion (in $\mathrm{J} / \mathrm{kg}$ )

$\rho \quad$ Density (in $\mathrm{kg} / \mathrm{m}^{3}$ )

$\chi \quad$ An Efficiency Factor
Abbreviations
FRM Fire Retardant Material
FTT Fire Testing Technology
HF Heat Flux
MF Mass Flux
MLR Mass Los Rate
MOD Mass Optical Density
SDC Smoke Density Chamber
SOD Specific Optical Density 


\section{Introduction}

Wood is widely used in global markets for structural applications [1]. It has been widely used throughout history in different applications including interior housing finishes, construction works, tools, weapons, transportation and decorative and art objects [2]. Natural timber is generally used in many applications in homes infrastructure, furnishing and decorations [3].

Fire is a rapid flammable reaction process causes heat, light, and various products to be released depending on the reactive materials and ventilation process. These fires occur occasionally and more likely in compartments than outdoors. In a compartment fire, localized temperatures up to $1100^{\circ} \mathrm{C}$ can be achieved. As a black body, compartment radiation of $200 \mathrm{~kW} / \mathrm{m}^{2}$ increases wood burning rates to $4.4 \mathrm{~mm} / \mathrm{min}$ [4]. In limited ventilation compartment, smoke is the major source of injury and death in a fire [5]. It is the cause of $39 \%$ of fire deaths in residential buildings and $46 \%$ of civilian fire injuries [6]. Civil defense of Jordan reported in 2018 that $7.7 \%$ of the total number of accidents with an average risk of 0.048 is due to fire in residence buildings [7]. It cause fear, or even death to occupants in near parts of the buildings due to smoke released from fire source or through mechanical ventilation systems. Furthermore, property losses increases significantly as smoke weakens firefighting efforts, which increasing the intensity of fire depending on the amount and rate of smoke generating in the fire. According to the building regulations (codes of fire and safety), the method used to prevent smoke from spreading is to install different types of inhibitors and shut down or closing the ventilation system in the case of fire [7].

Unfortunately, the risk of fire resulting from wood, wood products and additives is high, which limits their widespread use and applications [8]. To protect property and construction elements, fire retardant material (FRM) is used as a fire protective coatings. Smoke from wood flaming additives and coatings is a major cause of risky conditions in compartment fires [9]. The amount of smoke production affects the time available for occupants to escape. The requirement for effectual techniques to identify these toxic hazards is necessary at this stage of progress in fire safety research. [9].
Fire science, projects and researches have been very important in studying and analyzing fire hazards and designing safe evacuation plans. It also remains important for firefighting activities after the fire. In the United Kingdom, studies, in 2013/2014, showed that the number of claimed fires was 21,900. Dwelling fires has been the largest, it accounted for $44 \%$ of all main fires and $80 \%$ of all deaths. The major source of death, as reported, was due to gas, smoke or toxic fumes. $41 \%$ of death rate and $46 \%$ of injuries were caused by inhalation of toxic smoke [6]. As in the United Kingdom (UK), many studies have been conducted around the world on fire and smoke hazards because of the increasing of death numbers since 1960 [10]. This increase had been attributing to three main factors [11]:

Firstly was due to the increase of the use of complex materials such as polymers that produce incomplete combustion emissions. Secondly was due to the influence of modern buildings that increase energy consumption, which increases the burning temperature and rapid fire growth. Thirdly was due to the ventilation restrictions of modern day designs, which can slows down the fire spread, complicates the combustion and enhances the production of incomplete combustion products due to the limitation of fire by the amount of oxygen available to oxidize the fuel in cases were a restricted ventilation occurs and an abrupt changes in ventilation can have great effects on fire. These factors, joined with lifestyle changes, such as the increase in the amount of furniture (fire loads), their layout and physical composition, have helped to increase fire injuries from inhalation of toxic smoke [11]. Large amount of smoke generated by fires is considered as a major hazard particularly in the early stages following ignition, which is related to visibility problems and inhalations due to production of hazardous amounts of toxic gases. The reduction in visibility due to limited ventilation and smoke concentration leads to a critical situation for occupant's life protection and applications of fire safety provisions [12] and [9].

Several works have been carried out in order to find a correlations between visibility and optical density (OD) in limited ventilation environments [9], [13], [14] and [15]. Studies have found that at an optical density of (5.0 per meter), a person can only see a distance of 0.6 meters in front of him. It also concluded that the maximum visibility required was within an optical density of 0.08 per meter, 
which is equivalent to a minimum visibility of 10 meters.

Recent studies, as described in the literature, focus on ignition time, heat release rate, heat of combustion and concentration of carbon production but neglect the main factor that affects the amount of these products which is the burning rate or the mass loss rate (MLR). Burning rate or MLR are considered as an ignition standard of wood since it reveals the amount of pyrolysis and gaseous products during combustion [16].

Fire science is a rapidly developing field over the past few decades; from being an environmental issues to being a mechanical issues. Therefore, this paper is originated to study the set of variables that affect fire dynamics to increase fire safety for community and environment.

This paper comes in a series of published papers [3], [7] and [9] which include experimental studies of fire dynamic characteristics in many types of wood that are widespread in home structures and furniture in Jordan. In Jordan, homes do not implement public safety protection systems or fire insurance policies, and fire safety measures have not yet been fully standardized. In this case, prevention is better than treatment, and the use of wood and its additives to extend the time of fire growth until the arrival of the civil defence is essential.

The aim of this work is to examine, experimentally, the effect of heat flux on the fire characteristics such as; mass loss rate (MLR), mass flux (MF), mass optical density (MOD) and transmission $(\mathrm{T})$ by measuring smoke generated by wood samples under different Flaming combustion in limited ventilation compartment. This work investigates the influence of time-dependent incident heat flux (HF) as a major cause of fire behave; other characteristics such as smoke density and MLR have been taken into account as they reveal the amount of gaseous products during pyrolysis.

The results of this paper can be used in the preventive and operational fields in the pre-fire time and can also be used in the fields of investigation and environment in the following time. The results of this study can provide the bases for ventilation process and considerations of using natural woods in Jordan for different applications. The paper covers the experimental setups and methodology of the tested specimens and the overall results interpretations. Then, the concluding remarks is obtained. The work is ended by a number of tables, figures and charts, and through an updated and thorough reference list.

\section{Theoretical Background}

Please, Wood is a heterogeneous material and is also non-isotropic. It contains $(\sim 50 \%)$, hemicellulose $(\sim 25 \%)$ and lignin $(\sim 25 \%)$ whose values vary by wood types. Providing information on the burning rate and heat release rate of combustible solids is a necessary to evaluate flame behavior in real situations and estimate the contribution that combustible materials can make towards fully development in a limited ventilation environment [4]. Fire spread in woods is strongly dependent on the burning rate of wood and the ventilated mass transfer of oxygen. In this phenomenon, heat and mass transfer mechanisms are strongly combined. Changing any of these factors will fundamentally affect combustion dynamics and fire behavior [17].

For charring combustible materials like wood, the combustion is happened according to the following sequences of deformation based on the original mass of wood [18]:

Wood + Heat $\rightarrow$ Volatiles + Char

Volatiles $+\mathrm{Air} \rightarrow \quad$ Incomplete Products $+\Delta \mathrm{Hc}$, Vol

Char + Air $\rightarrow$ Incomplete Products $+\Delta \mathrm{Hc}$, Char

$\Delta \mathrm{Hc}$, wood $\quad \Delta \mathrm{Hc}, \mathrm{vol}^{+} \Delta \mathrm{Hc}$, Char

The heat release rate ( $\dot{Q}^{\prime \prime}{ }_{c}$ ) may be expressed in terms of the primary variables, the burning rate of volatiles $(\dot{\mathrm{m}})$ and heat of combustion $\left(\Delta \mathrm{H}_{\mathrm{c}}\right)$, thus:

$$
\begin{aligned}
& \dot{Q}_{c}{ }^{\prime \prime}=\dot{m} " \chi \Delta H_{c} \\
& \dot{Q}_{c}=\dot{m} " \chi \Delta H_{c} A_{F}
\end{aligned}
$$

Where $\chi$ is an efficiency factor that takes into account incomplete combustion and $\mathrm{A}_{\mathrm{F}}$ is the fuel surface area. The flame heat flux can be deduced from the steady burning rate data in which Equation (1) becomes,

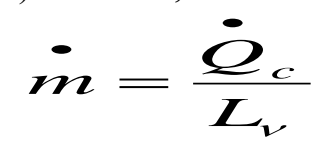


Where $\mathrm{L}_{\mathrm{v}}$ is the heat required to produce the volatiles or 'heat of gasification'.

The mass loss rate (MLR) is an important parameter for describing the heat release rate. The wood mass loss rate is given by:

\section{$M L R=\left\{\begin{array}{l}\text { Mass of wood beforburning } \\ - \text { Mass of wood afterburning }\end{array}\right\} /$ Time}

The percentage mass loss rate (MLR \%) is obtained from Equation (3).

$$
M L R \%=\left\{\begin{array}{c}
\begin{array}{l}
\text { Mass of wood before burning } \\
\text {-Mass of wood after burning }
\end{array} \\
\begin{array}{c}
\text { Mass of wood } \\
\text { before burning }
\end{array}
\end{array}\right\}
$$

Three important thermal properties affecting the heat flow rate are; specific heat, thermal conductivity and thermal diffusivity. The relationship between these properties is given by:

Where

$$
\propto=\frac{\mathrm{k}}{\rho \mathrm{c}}
$$

$\alpha=$ thermal diffusivity, $\rho=$ density $\mathrm{k}=$ thermal conductivity and $\mathrm{c}=$ specific heat.

In fire scenarios, vents, solids and furnishings play an important character in fire development, the time for materials to ignite helps to explain or predict the steps of fire growth [18]:

1. The solid is heated up, which raising its temperature to produce pyrolysis and gaseous fuel.

2. The grown fuel vapor is transported through the fuel layer where the ventilated ambient air is mixed with it.

3. As it reaches pilot, there will be another moment in time for the chemical reaction to proceed to Flaming combustion.

$$
t_{i g}=t_{p y}+t_{m i x}+t_{c h e m}
$$

Where:

$t_{p y}$ is the time for the solid to achieve $t_{p y}$

$t_{\text {mix }}$ is the diffusion time required for the fuel and oxygen to reach the pilot

$t_{\text {chem }}$ is the time required for the flammable mixture to proceed to combustion once at the pilot

The burning of wood and charring materials is a time dependence, it is not steady [18]. Ignition time is some inverse function of heat flux, burning characteristics can be controlled by controlling the thermal properties accompanied in thermal inertia $\mathrm{k} \rho \mathrm{c}$. This means; the earlier the wood is heated, the earlier it ignites in which [18],

$$
\dot{m}_{F}^{\prime \prime} \propto \frac{1}{\sqrt{t}}
$$

Smoke is a problem for occupants and evacuation plans and firefighters efforts because visibility range is decreasing when the concentration of particles accumulating in the compartment. To select materials suitable for such cases, standard measurements of optical smoke density have been performed through which the amount of smoke can be determined by optical measurement and the flow of smoke or can be determined by burning objects directly. Test methods used were of two types [19]: Those where light transmittance measurements are made directly on smoke aerosols and those that can be weighed or measured through light transmission.

The yield of particulate smoke from a burning material is assessed by collecting the smoke in a known volume and determining its optical density under standardized conditions. A beam of light going through the smoke particles is expressed as a percentage of overall Transmittance $(T)$ and Specific Optical Density of smoke (Ds) as defined in Equations 6 and 7

$$
\begin{aligned}
& \mathrm{T} \%=100 \frac{\mathrm{I}}{\mathrm{I}_{\mathrm{o}}} \\
& \mathrm{D}_{\mathrm{s}}=\frac{\mathrm{V}}{\mathrm{AL}} \log _{10} \frac{\mathrm{I}_{0}}{\mathrm{I}}=\frac{\mathrm{V}}{\mathrm{AL}} \log _{10} \frac{100}{\mathrm{~T}}
\end{aligned}
$$

where $\mathrm{V}$ is the volume of the chamber where the smoke is accumulated $\left(0.510 \mathrm{~m}^{3}\right), \mathrm{A}$ is the normal area exposed in front of the heat flux, it was $\left(0.00424 \mathrm{~m}^{2}\right), \mathrm{L}$ is the long path considered to measure the transmittance $\mathrm{T}$, which was $(0.914 \mathrm{~m})$, $\mathrm{I}_{0}$, and I are, respectively, the light intensity before and after ignition.

The optical density per meter $\left(D_{L}\right)$ is given by,

$\mathrm{D}_{\mathrm{L}}=\frac{\mathrm{A}}{\mathrm{V}} \frac{\mathrm{D}_{\mathrm{S}}}{1}=\mathrm{L} \cdot \log _{10} \frac{\mathrm{I}_{0}}{\mathrm{I}}$

The generation of smoke in fires relates to a reduction in visibility. Visibility is considered as a main parameter that affects the time of escape, so the distance between escape routes. The recommended relationship between (DL) and visibility $(\mathrm{S})$ is given below [20]:

$\mathrm{S}=\frac{1}{\mathrm{D}_{\mathrm{L}}}=\frac{\mathrm{V}}{\mathrm{A}} \frac{1}{\mathrm{D}_{\mathrm{S}}}=\frac{120}{\mathrm{D}_{\mathrm{S}}}$ 
To convert percentage of transmittance obtained to specific optical density (Ds), Beer's laws is applied by the following equation:

$\mathrm{D}_{\mathrm{s}}=\mathrm{G} \log _{10}\left(\frac{100}{\mathrm{~T} \%}\right)$

Where $\mathrm{G}$ is a geometrical coefficient for present chamber it was (132) which would be directly proportional to the chamber volume in which the smoke is accumulating $\left(0.510 \mathrm{~m}^{2}\right)$ and indirectly proportional to path length $(0.914 \mathrm{~m})$ and area producing smoke $\left(0.00424 \mathrm{~m}^{2}\right)$.

Another predictive parameter relates the specific optical density determined by the mass loss rate suggested by [Hao (1988)], which is known as the mass optical density (MOD) expressed in $\mathrm{cm}^{2} / \mathrm{g}$ defined as:

$$
\text { MOD }=\frac{A_{\mathrm{S}}}{\mathrm{m}}
$$

where $\mathrm{m}=$ mass loss of specimen in $\mathrm{gm}$.

\section{Experimental Setup:}

Experiments were carried out on the ignition of wood samples using the burning rate and the radiant heat flux in a smoke density chamber (SDC) apparatus shown in Figure 1.

The smoke-density chamber was developed to evaluate the potential amount of smoke generated from flammable substances in 1966 by Fire Research Section at the National Bureau of Standards (NBS) [21].The apparatus shown in Figure 1 is located in the fire safety engineering laboratory at Prince Hussein Bin Abdullah II Academy of Civil Protection, Al-Balqa Applied University. The NBS apparatus is usually used to estimate the amount of smoke generated for different flaming and non-flaming combustible materials. It used to measure the burning rate, smoke density, transmittance and visibility. It consists of a sealed test enclosure, an electrical furnace emits continuous radiation heat flux with a two constant capacities of (25 and 50$) \mathrm{kW} / \mathrm{m}^{2}$. A data acquisition system, a scanner and a (HP) software used in experimentation were used to monitor the required measurements.

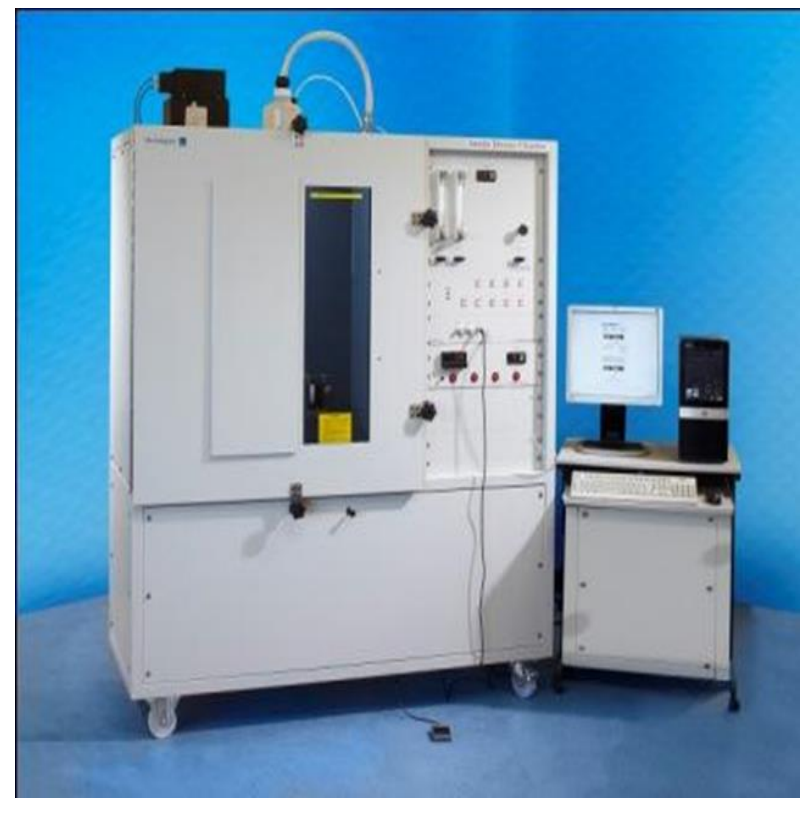

Fig.1: Typical arrangement of test apparatus

The apparatus was calibrated and the samples were prepared and tested in accordance with the procedure described in ISO 5659 under Flaming and Non-Flaming combustion [9]. The experimental procedure consisted of exposing the samples, in the horizontal orientation, to a constant irradiance heat flux. The time was measured while the required data were recorded every two seconds during a 600 second period. The samples chosen were taken from Jordan wood market. Samples to be tested $(75 \times 75$ $\mathrm{x} 10 \mathrm{~mm}$ ) must be wrapped in aluminum foil to preserve the insulated borders from outside variable condition and to prevent dripping in a horizontal orientation. The samples were chosen based on statistical information of the Jordan commercial market. It is about $40 \%$ of the overall hardwood plywood industry in Jordan [9]. Smoke Density Chamber (SDC) apparatus in Figure 1 is commonly used to measure the burning rate, the specific optical density and transmittance. The conditions to which the specimens are exposed are:

- A radiation heat flux of $25 \mathrm{~kW} / \mathrm{m}^{2} \pm 1 \mathrm{~kW} / \mathrm{m}^{2}$ accompanied with pilot flame

- An irradiance of $50 \mathrm{~kW} / \mathrm{m}^{2} \pm 1 \mathrm{~kW} / \mathrm{m}^{2}$ accompanied with pilot flame

- An irradiance of $50 \mathrm{~kW} / \mathrm{m}^{2} \pm 1 \mathrm{~kW} / \mathrm{m}^{2}$ without pilot flame 
Experiments to determine the MLR of the wood samples were performed together with the specific optical density experiments. During the tests, an electronic balance was placed under the sample to measure the mass loss rate while other data was accompanied at the same moment. The mass of the samples was recorded using the mass balance that records the readings directly over the time. The mass readings were recorded every thirty seconds for about 600 seconds. After 600 seconds, the flux is turn off and the samples is drawn out. The output is as shown in figure 2 for unpainted case and figure 3 for painted one. By the results, the paint increases the amount of char produced, which decreases the area exposed and amount of volatiles as shown in Figure 3.

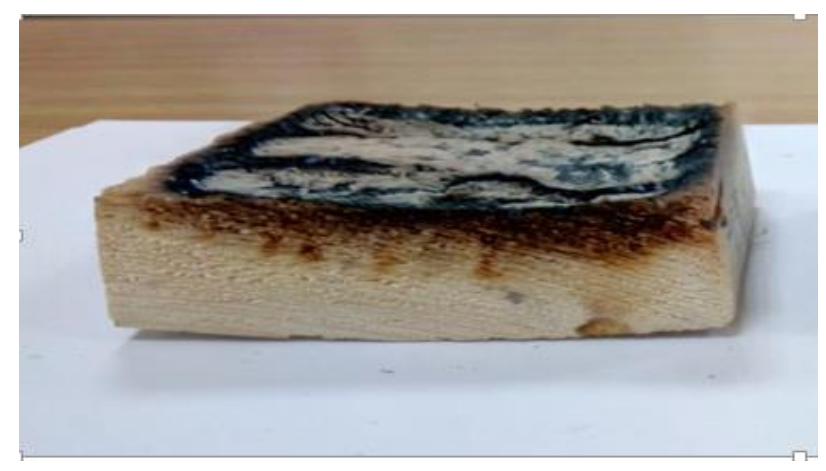

Fig. 2 Unpainted Beech wood under an irradiance of $25 \mathrm{~kW} / \mathrm{m}^{2}$

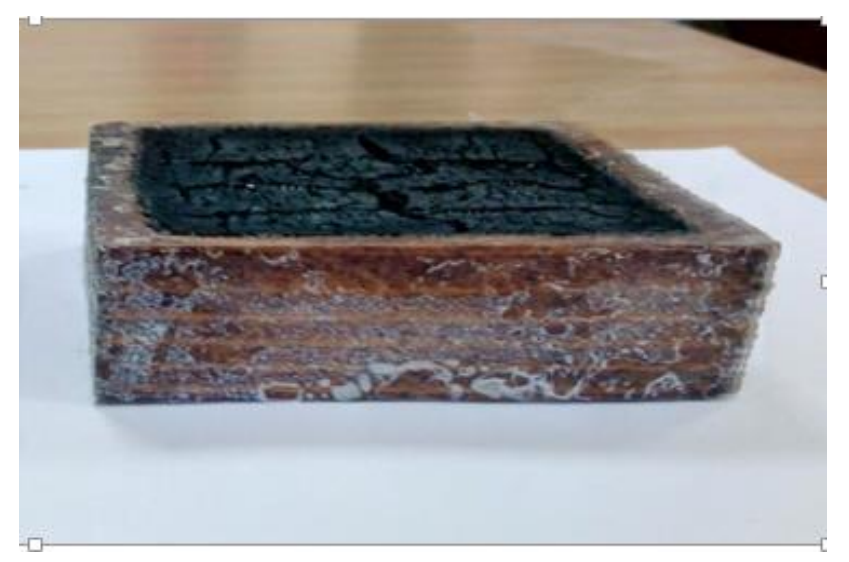

Fig. 3 Painted Beech wood under an irradiance of 25 $\mathrm{kW} / \mathrm{m}^{2}$

\section{Results and Discussion}

Wood is a natural organic and isotropic composite material that consists of cellulosic fibers and lignin. Burning of wood always requires to breakdown the bonds to produce fuel vapors depends on the types of wood and its composition. They release heat at different temperatures, hemicellulose decomposes first at low temperatures $\left[200-260^{\circ} \mathrm{C}\right]$ then cellulose at moderate temperatures of $\left[240-350^{\circ} \mathrm{C}\right]$, and finally lignin at higher temperatures of $\left[280-500^{\circ} \mathrm{C}\right]$ due to its heavily cross-linked structure and high molecular weight [4] and [22]. The burning rate of wood samples is often dependent on the thermal properties of the wood samples. It was calculated through the calorific values [4], density and thermal conductivity. Density and thermal conductivity were obtained, experimentally, as listed in Table 1.

Table 1: Wood chemical and physical properties, as significant inputs related to the experiment.

\begin{tabular}{|c|c|c|c|c|c|}
\hline Sample & 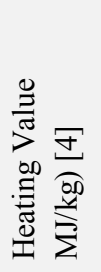 & 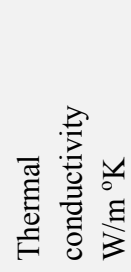 & 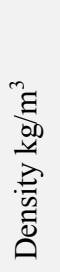 & 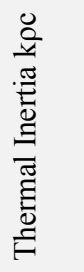 & 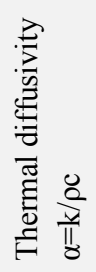 \\
\hline Beech & 20.380 & 0.1397 & 800 & 2277 & 8.68 \\
\hline Oak & 19.030 & 0.1051 & 596 & 1192 & 8.95 \\
\hline Rhamnus & 25.217 & 0.1048 & 444 & 1173 & 9.36 \\
\hline Abies & 26.330 & 0.1047 & 409 & 1127 & 9.66 \\
\hline
\end{tabular}

\subsection{Burning Rate and Mass Loss Rate (MLR)}

Burning rate (BR) and Mass loss rate (MLR) have been considered as an ignition standard of compostable materials as it reflects the quantity of volatiles and vaporous produces through combustion [16]. MLR is an important factor in achieving an appropriate volatile concentration of fuel and ventilated air, which leads to the oxidation of pyrolysis gases and thus to Flaming combustion. The results are presented in terms of mass measurements for the representative tests with time as shown in figures $(4,5$ and 6$)$. These particular tests were conducted with a Flaming and NonFlaming heat flux of 25 and $50 \mathrm{~kW} / \mathrm{m}^{2}$. As the wood sample is heated by heat flux, it loses mass due to pyrolysis production and energy conversions. As indicated in Figures 4, 5 and 6, the samples mass loss for both Flaming and Non-Flaming ignitions increases as the heat flux increases for all levels of heat flux. The results show the mass of each type of wood decreases with the time of burning due to further oxidative pyrolysis that occurs. Smoke 
production depends on burning materials, burning rate and other factors including ventilation, oxygen supply and type of combustion.

A slight change has been occurred at the beginning $(60 \mathrm{~s})$ due to time needed for fuel (wood sample), oxygen and heat to combine, at which moisture is evaporated and the wood is progressively heated and changes begin to occur in its structure. The results show the burning rate of Beech is slightly significant and the behaviors of Rhamnus and Oak were in similar trends. The results show the burning rate of Beech is (1.86 $\mathrm{gm} . / \mathrm{min}$ ) that has the higher thermal inertia (2277), and Abies is $(0.84 \mathrm{gm} . / \mathrm{min})$ that has the lower thermal inertia (1127), which is comparatively low compared with the other types of wood samples.

The temporal variations of mass and MLR for various tested specimens under the same conditions of constant heat flux of $\left(25 \mathrm{~kW} / \mathrm{m}^{2}\right)$ in horizontal orientation are presented in Figure 4. As an absolute value, Beech has lost, from its mass, more than other sample (18.6 gm.). It exhibited a high percentage of burning rate reaches $41.7 \%$ of its initial mass, which is considered the greatest mass loss among all samples, since it has the lower density and has the lower percentages of lignin $22 \%$.

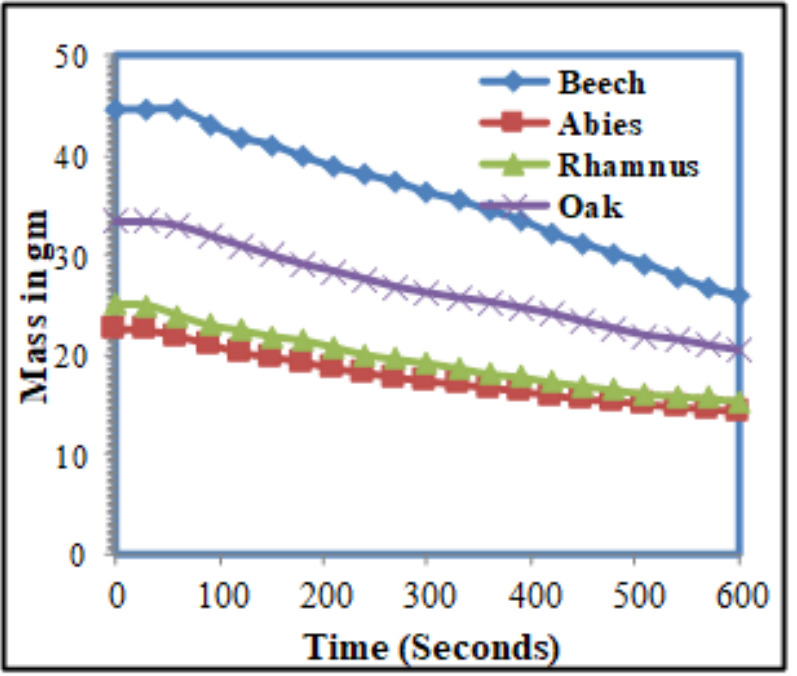

Fig. 4: Temporal mass loss for wood samples at constant Flaming heat flux of $25 \mathrm{~kW} / \mathrm{m}^{2}$.

Abies sample has lost $36.9 \%$ during 600 seconds of burning, which is considered the lowest mass loss among all samples. This can be explained by the lower thermal inertia of Abies. Abies wood has higher percentages of lignin $31.08 \%$ [23] that consumes the most of energy released. It influences the 'combustibility ratio by altering $\Delta \mathrm{Hc}$ and $\mathrm{Lv}$ and releases volatiles at higher temperatures, typically $\left(280-500{ }^{\circ} \mathrm{C}\right)$. Where the mass loss of major wood compounds took place, the highest being recorded at $280{ }^{\circ} \mathrm{C}$ [23] since lignin is known by a higher heating capacity compared to the cellulose and hemicellulose. By the time the MLR becomes limited as the layer at the surface becomes ash, which affects the pyrolysis process significantly.

\subsection{Effect of Heat Flux (HF)}

The spread of fire depends heavily on the heat flux and fuel burning rate, which is strongly associated with the heat transfer and mass transport mechanisms. Both mechanisms increase the amount of fuel vapor required for combustion [17]. Radiation heat flux is significant variable in fire growth and growth period. It depends on the type of flow, combustion products and chemical structures that encourage the wood to ignite, the flame to spread and burning rate increase [18].

Figures 5 and 6 show the mass measurements for two illustrative tests. These particular tests were performed with a heat flux of $50 \mathrm{~kW} / \mathrm{m}^{2}$.

In Figure 5, the heat flux was doubled (50 $\mathrm{kW} / \mathrm{m}^{2}$ ). As seen by the figure, the MLR has been affected significantly by the changed in heat flux [16]. MLR and MLR\% are more pronounced by high heat fluxes. For high heat fluxes, ignition takes place away from the surface in a short time. In the case of low heat fluxes, ignition occurs near the surface and takes a long time [24]. As seen in Figure 5 , the mass of the samples is decreased by the burning time. Which depends mainly on the amount of heat flux, the duration of interaction with the heat source, the thermal properties of the boundaries and the ability to cause smoldering combustion. As shown in Figure 5, the turn in the MLR curve at about 30 seconds indicates ignition (Flashing ignition), after that, the MLR dramatically increases. The results showed that the percentage loss of Rhamnus (38.6\%) and Abies (38.9\%) were close. It shows the mass gradients are similar, despite the variations in thermal properties.

Figures 5 shows the MLR measurements as a time variation for a typical $50 \mathrm{~kW} / \mathrm{m}^{2}$ heat flux test. As shown in Figure 5, the samples mass appear to decrease depending on the time of the burning, 
which depends mostly on the period of interaction between the compostable material and the heat flux, the thermal properties of the wood samples and the ability to reach the burning combustion. The results show that the mass gradient of beech samples is still more significant. The results show that the beech MLR is the highest among them $(3.38 \mathrm{~g} / \mathrm{min})$ and that of Abies is the lowest among them (1.21 $\mathrm{g} / \mathrm{min}$ ). Figure 5 shows no significant change in MLR and mass gradient for both Rhamnus and Abies. Since Abies is the least density and thermal inertia among them, it lost $56.8 \%$ during 600 seconds of burning, were the thermal inertia $\mathrm{k \rho c}$ is significant, which increases as temperature increases. By comparing the results of Figure 5 with the results of Figure 4, the results show the MLR depends on time and the imposed surface heat flux.

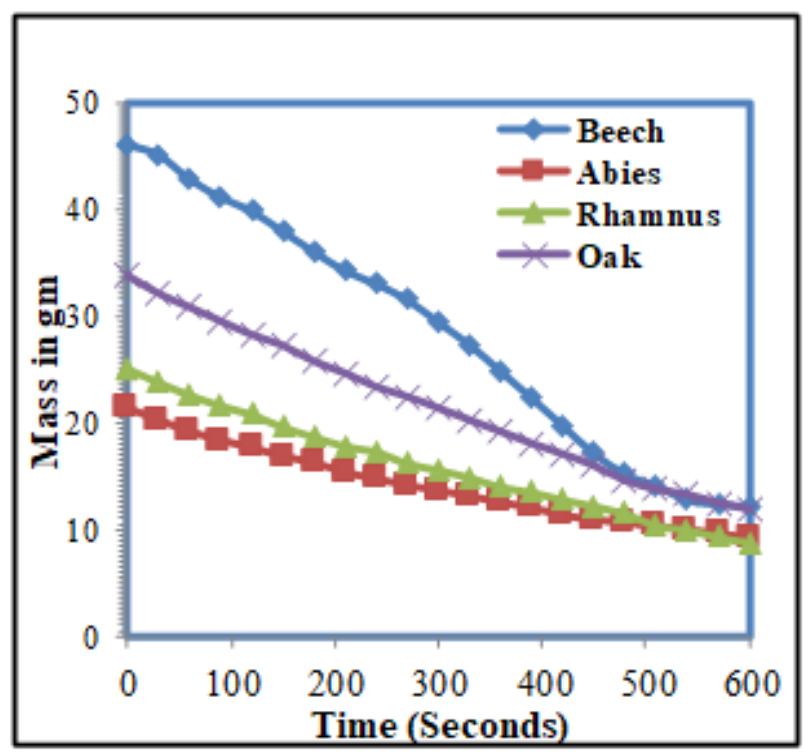

Fig. 5: Temporal mass loss for wood samples at constant Flaming heat flux of $50 \mathrm{~kW} / \mathrm{m}^{2}$.

Figures 6 illustrates the time variations of MLR for wood samples exposed to Non-Flaming combustion heat flux of $\left(50 \mathrm{~kW} / \mathrm{m}^{2}\right)$. Figure 6 shows the effect of Non-Flaming heat flux $\left(50 \mathrm{~kW} / \mathrm{m}^{2}\right)$ on MLR as it reaches $74.6 \%$ for beech wood. It reflects the amount of heat flux with no effect of the Flaming combustion. The results show that the mass gradient of Beech samples is still more significant $(3.38 \mathrm{~g} / \mathrm{min})$ and that of Abies $(1.21 \mathrm{gm} . / \mathrm{min})$ is still relatively the lower among all samples. The comparison of results in Figure 6 with those shown in Figure 5 illustrates the ideal and experimental data for the MLR of both Flaming and Non-Flaming combustion at $50 \mathrm{~kW} / \mathrm{m}^{2}$. Changing Flaming combustion (from Flaming to Non-Flaming) at the same heat flux levels has little impact on wood fire behaviors. Referring to equation 3, this is clearly true because the MLR is based on the amount of heat generated and the heat of gasification rather than the Flaming conditions. Therefore, radiate heat flux is significant regardless its Flaming condition.

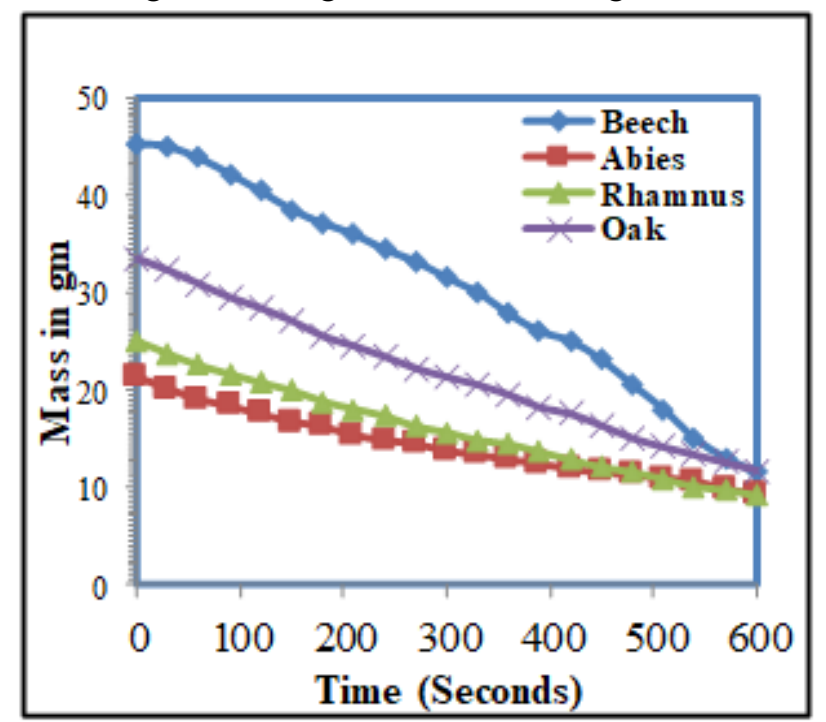

Fig. 6: Temporal mass loss for wood samples at constant Non-Flaming heat flux of $50 \mathrm{~kW} / \mathrm{m}^{2}$.

MLR is an ignition parameter that indicates the rate of heat release and changes in flame temperature that increase as heat flux increases. Tables 2 and 3 summarize the numerical results of Figures 4, 5 and 6 for efficient comparisons, comments and recommendations. The samples were exposed to continuous heat fluxes of (25 and 50 $\mathrm{kW} / \mathrm{m}^{2}$ ). Comparing the MLRs results for wood samples under heat flux in Flaming and NonFlaming cases show a significant effect for the amount of heat flux despite the change in Flaming conditions.

Table 2 shows the mass loss rates (MLR) and percentage mass loss (MLR\%) for the different samples, with different radiative heat fluxes. Tests were performed at 25 and $50 \mathrm{~kW} / \mathrm{m}^{2}$ during 600 seconds. The results in Table 2 show the MLRs as the external radiant heat flux changes at the same Flaming conditions. During Flaming combustion, the samples showed a high increase in the burning rate and the mass loss rate. This increase in the rate of mass loss increases as the heat flux increases due to the increase in the amount of activated gases and pyrolysis produced during combustion as shown in figures 4, 5 and 6 . As shown in Table 2, increasing 
heat flux levels from $25 \mathrm{~kW} / \mathrm{m}^{2}$ to $50 \mathrm{~kW} / \mathrm{m}^{2}$ has a significant effect on wood fire behaviors. During Flaming combustion, samples at heat flow of (50 $\left.\mathrm{kW} / \mathrm{m}^{2}\right)$ have lost a larger MLR\% than that at $(25$ $\mathrm{kW} / \mathrm{m}^{2}$ ) where the increases in MLR depends on the heat release rate and the level of heat flux.

Table 2: MLR and percentage loss for Flaming combustion at 25 and $50 \mathrm{~kW} / \mathrm{m}^{2}$ heat flux.

\begin{tabular}{|l|l|c|c|c|c|}
\hline $\begin{array}{l}\text { Heat Flux } \\
\text { in W/m }\end{array}$ & & Beech & Abies & Rhamnus & Oak \\
\hline Flaming 25 & $\begin{array}{l}\text { Mass } \\
\text { Loss }\end{array}$ & 18.6 & 8.4 & 9.7 & 13.0 \\
\hline Flaming 50 & $\begin{array}{l}\text { Mass } \\
\text { Loss }\end{array}$ & 34.2 & 12.5 & 16.3 & 22.0 \\
\hline $\begin{array}{l}\text { Flaming } \\
25\end{array}$ & $\begin{array}{l}\text { MLR } \\
\%\end{array}$ & 41.7 & 36.9 & 38.6 & 38.9 \\
\hline $\begin{array}{l}\text { Flaming } \\
50\end{array}$ & $\begin{array}{l}\text { MLR } \\
\%\end{array}$ & 74.3 & 58.7 & 64.9 & 65.1 \\
\hline
\end{tabular}

Table 3 shows MLR and MLR\% for the different samples, with different Flaming conditions at the same heat flux. Tests were performed at constant heat flux of $\left(50 \mathrm{~kW} / \mathrm{m}^{2}\right)$ during 600 seconds. Samples showed an equal amount of MLR\% despite the different Flaming conditions. At a maximum, MLR\% of beech has increased from $41.7 \%$ to $74.3 \%$ with increasing the Flaming heat flux from 25 to $50 \mathrm{~kW} / \mathrm{m}^{2}$. The MLR\% has decreased from $74.3 \%$ to $74.2 \%$ as ignition changed from Flaming to Non-Flaming combustion at $50 \mathrm{~kW} / \mathrm{m}^{2}$. This indicates that the rate of change in MLR\% with Flaming conditions does not depend entirely on ignition conditions. Referring to equations 1 and 2, this is mathematically true.

Table 3: MLR and percentage loss for Flaming and Non-Flaming combustion at $50 \mathrm{~kW} / \mathrm{m}^{2}$ heat flux

\begin{tabular}{|l|l|c|c|c|c|}
\hline $\begin{array}{l}\text { Heat Flux } \\
\text { in W/m }\end{array}$ & & Beech & Abies & Rhamnus & Oak \\
\hline $\begin{array}{l}\text { Flaming } \\
50\end{array}$ & $\begin{array}{l}\text { Mass } \\
\text { Loss }\end{array}$ & 34.2 & 12.5 & 16.3 & 22.0 \\
\hline $\begin{array}{l}\text { Non } \\
\begin{array}{l}\text { Flaming } \\
50\end{array}\end{array}$ & $\begin{array}{l}\text { Mass } \\
\text { Loss }\end{array}$ & 33.6 & 12.2 & 15.9 & 21.8 \\
\hline $\begin{array}{l}\text { Flaming } \\
50\end{array}$ & $\begin{array}{l}\text { MLR } \\
\%\end{array}$ & 74.3 & 58.7 & 64.9 & 65.1 \\
\hline $\begin{array}{l}\text { Non } \\
\text { Flaming } \\
50\end{array}$ & $\begin{array}{l}\text { MLR } \\
\%\end{array}$ & 74.2 & 57.3 & 63.6 & 65.1 \\
\hline
\end{tabular}

\subsection{Specific optical density}

Smoke is a key factor in the success of escape from fire. If the fire is in its early stages, the biggest problem people are challenged with escaping from fire is the low visibility associated with the intensity of smoke. Reduction of visibility range by smoke makes people evacuation from building difficult or even impossible [25]. Furniture and limited ventilation are the potential source of smoke, which is one of the main causes of loss of life in fire whose components involve wood. Therefore, samples of wood that is widely used in furniture in Jordan were tested concurrently with the MLR using a smoke density chamber.

There is a wide variation in the composition and structures of wood, the source of the different samples. The rate of smoke generated from these samples depends on the chemical properties of wood as well as their physical properties. The specific optical density was recorded using a data logger connected to the smoke density chamber used to determine the smoke generated by wood samples. Readings were recorded every thirty seconds for approximately 600 seconds.

An almost identical trend was observed for the smoke accumulation\% against time curves for all samples tested as shown in Figure 7. A linear increase in the smoke generation process was observed, resulting in a linear relationship that continued over time until the final reading of the accumulated smoke was reached.

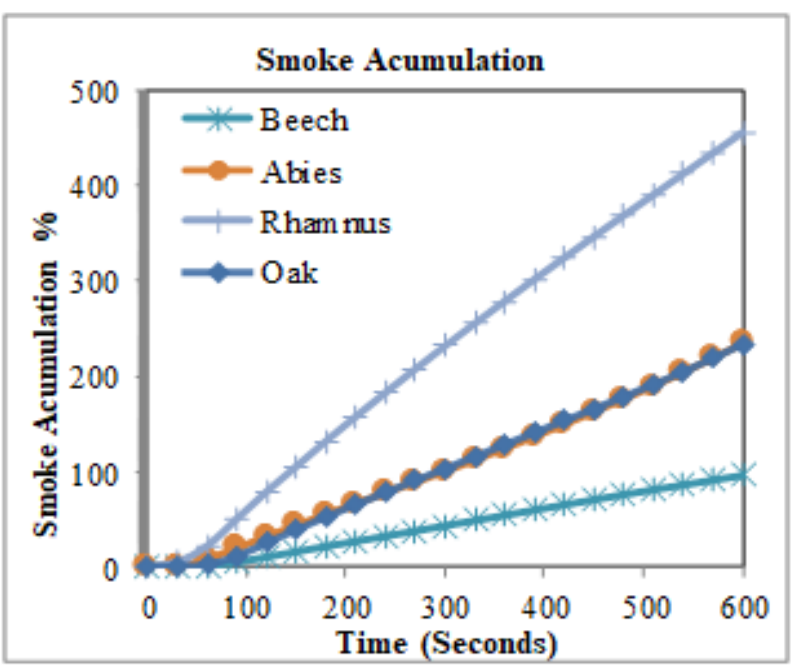

Fig. 7: Smoke percentage accumulation at constant

Flaming heat flux of $25 \mathrm{~kW} / \mathrm{m}^{2}$. 
In this work, several experiments have been conducted to study the amount of smoke concentrated over time in a particular experimental case. The results show the transmittance and the amount of specific optical density over time for both Flaming and Non Flaming combustion. Fire Testing Technology (FTT) is used for wood samples using radiating heat flux in horizontal orientation within an adiabatic chamber of fixed volume. A column light beam and photomultiplier tube were oriented vertically into the chamber to reduce the stratified effects of smoke. It measures the percent light of transmittance and specific optical density (SOD) by computing the concentration of smoke generated from wood samples during experiments by the received heat flux.

The most common method to measure the density of smoke today is to use a light source and a photoelectric cell. The electrical output of the cell can be used as a measure of light dilution due to the intensity of smoke. Attempts have been made to relate the percent light transmittance to the optical density and quantitative smoke concentration.

The results show the rate of specific optical density over time and comparisons between the amount of smoke produced during flamig and NonFlaming combustion. Figures 8, 9 and 10 show the optical density of smoke per sample of wood depending on different heat fluxes and Flaming conditions. Figure 8 shows the optical density of smoke for wood samples at a thermal heat flux of $\left(25 \mathrm{~kW} / \mathrm{m}^{2}\right)$. As the results show, the general trends of changes in the specific optical density over time are similar in all samples. The results show the specific optical density increases with the burning time to maximum value and then decline. This is due to the rise in temperature, which breaks the chemical chains between the sample atoms, causing an increase in the MLR and the amount of smoke produced from the sample.

There was a considerable change at the beginning of the 60 seconds, which is due to the time required for fuel (wood sample), oxygen and heat to combine and then increases rapidly to reach their higher values. According to Figures 6 and 8, beech, which has the higher values of mass loss rate, has lower values of specific optical density (5.587) compared to other samples. Rhamnus has the highest value (28.61) and grew even early in (60 seconds).

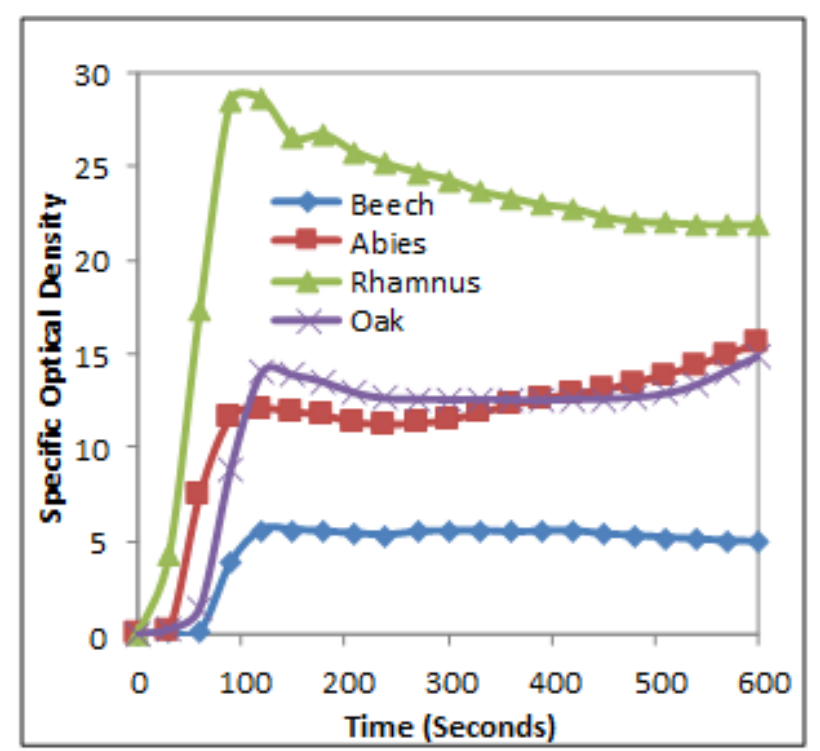

Fig. 8: Specific optical density of samples at constant

\section{Flaming heat flux of $25 \mathrm{~kW} / \mathrm{m}^{2}$.}

The same result shown in Figure 8 is repeated in Figure 9 despite the change in the external thermal flow from 25 to $50 \mathrm{~kW} / \mathrm{m}^{2}$. In this study, the samples were exposed horizontally and the heat flux radiated vertically down to the surface of the sample. Horizontal orientation causes stronger interaction between external radiation and decomposition products. As shown in Figure 9, the specific optical density in the samples appears to increase with the time of burning. It depends on the temperature, duration of interaction with the heat source, thermal properties of the boundaries and the ability to reach the smouldering combustion. This can be due to changes in gas composition and particle distribution before and after ignition. However, no sudden increase in the specific optical density was observed.

Initially, the specific optical density increases slowly, and then becomes more and more significant. Wood samples behave in the same trends despite variances in physical characteristics except beech, which behave in different way. The measured peak values of beech wood are up to (159.2 in 480 seconds) with a sudden increase observed at 330 seconds while it (28.7 after 60 seconds) for Abies, which releases volatile at higher temperatures. Figure 9 shows no significant difference in specific optical density between Oak and Rhamnus. 


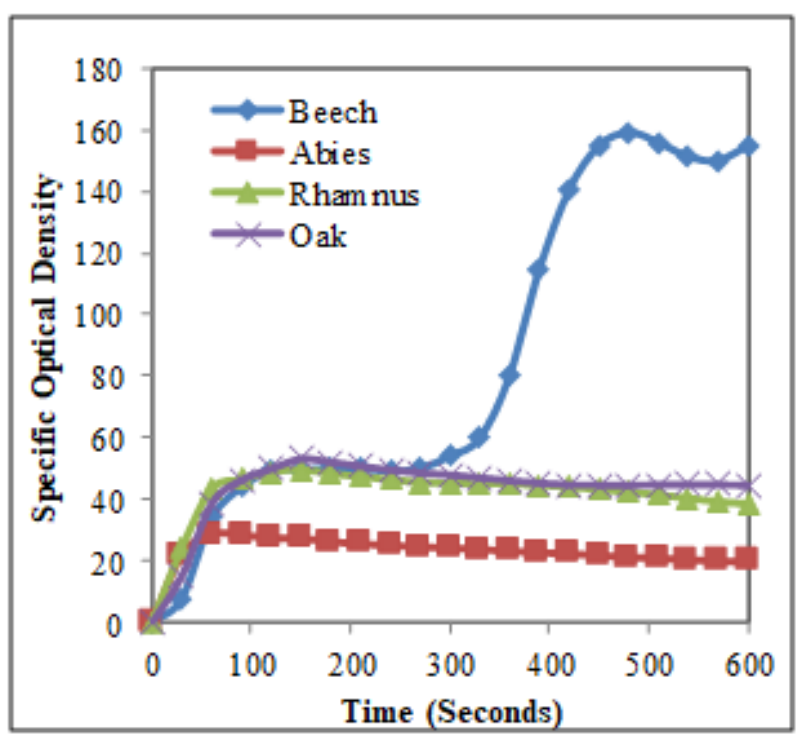

Fig. 9: Specific optical density of samples at constant

Flaming heat flux of $50 \mathrm{~kW} / \mathrm{m}^{2}$.

By comparing the results of Figure 9 with those of Figure 8, the results show that increased heat flow levels from $25 \mathrm{~kW} / \mathrm{m}^{2}$ to $50 \mathrm{~kW} / \mathrm{m}^{2}$ have a significant impact on fire behaviors and smoke optical density. The results show the gap between the curves of $25 \mathrm{~kW} / \mathrm{m}^{2}$ and $50 \mathrm{~kW} / \mathrm{m}^{2}$ is large and depends on wood types since the incident radiation has a very strong effect on the growth of decomposition products within the wood.

Figure 10 shows the results of specific optical density that cover the Non-Flaming combustion heat flux of $\left(50 \mathrm{~kW} / \mathrm{m}^{2}\right)$. Peak values reach 707.2 for beech at 450 seconds despite ignition time started late. And those for Abies reach 106.2 at 180 seconds, which are relatively low compared to other species. Large amount of smoke has been produced in Non-Flaming combustion due to the smoldering combustion. This explains the increase of smoke concentration in the box thus an increase of specific optical density.

Table 4 and 5 summarize the results obtained from figures 8, 9 and 10. The results included in these tables show the significant impact of flaming conditions despite the constant stability of the heat flux of $\left(50 \mathrm{~kW} / \mathrm{m}^{2}\right)$.

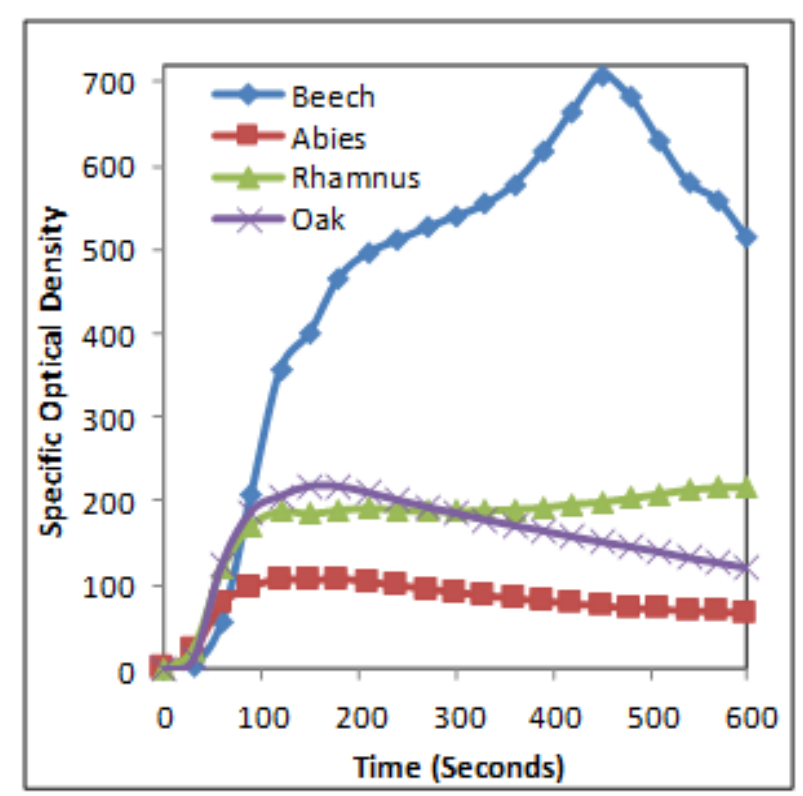

Fig. 10: Specific optical density of samples at constant

\section{Non-Flaming heat flux of $50 \mathrm{~kW} / \mathrm{m}^{2}$.}

Equation 11 shows the mass optical density (MOD) proportional to time. However, there is a stronger dependency of MOD on heat flux and flaming conditions. Table 4 shows the estimated results of MOD and MOD ratios in different flaming conditions. For beech wood, the MOD ratio based on the maximum values is the highest 5.13; as for the Abies, it's 3.77. Based on the average MOD values, it is 5.58 for Beech and 3.61 for Abies.

Table 5 represents the values of maximum optical density and visibility resulting from the experiment under the specific test condition according to ISO5659. This result show that all samples produce smoke in larger amount for NonFlaming combustion. Comparing the results of Figure 10 with those in Figure 9, changing ignition conditions at the same flux levels of $50 \mathrm{~kW} / \mathrm{m}^{2}$ has a significant impact on wood fire behaviors and smoke optical density. Visibility is not an output factor that is measured straight from the apparatus. It is estimated from the optical density, transmittance or smoke concentration. It has been calculated using equation 9 , and is presented in table 5. Although the flaming conditions have little effect on the MLR\% listed in Table 3, they have a significant effect on the specific optical density and therefore on visibility. Visibility values are lower for Non-Flaming Combustion, and the lowest value is for beech wood $(0.17 \mathrm{~m})$. 
Table 4: Maximum and average mass optical density for wood sample

\begin{tabular}{|c|c|c|c|}
\hline & \multicolumn{3}{|c|}{$\begin{array}{l}\text { Maximum mass optical density }\left(\mathrm{cm}^{2} / \mathrm{g}\right) \text { at } \\
50 \mathrm{~kW} / \mathrm{m}^{2} \text { heat flux }\end{array}$} \\
\hline $\begin{array}{l}\text { Type of } \\
\text { wood }\end{array}$ & $\begin{array}{c}\text { Flaming } \\
\text { Combustion }\end{array}$ & $\begin{array}{c}\text { Non-Flaming } \\
\text { Combustion }\end{array}$ & $\begin{array}{l}\text { MOD } \\
\text { Ratio }\end{array}$ \\
\hline Beech & 0.0174 & 0.0893 & 5.13 \\
\hline Oak & 0.0102 & 0.0422 & 4.13 \\
\hline Rhamnus & 0.0129 & 0.0511 & 3.96 \\
\hline \multirow[t]{2}{*}{ Abies } & 0.0098 & 0.0369 & 3.77 \\
\hline & \multicolumn{3}{|c|}{$\begin{array}{l}\text { Average mass optical density }\left(\mathrm{cm}^{2} / \mathrm{g}\right) \text { at } 50 \\
\qquad \mathrm{~kW} / \mathrm{m}^{2} \text { heat flux }\end{array}$} \\
\hline $\begin{array}{l}\text { Type of } \\
\text { wood }\end{array}$ & $\begin{array}{c}\text { Flaming } \\
\text { Combustion }\end{array}$ & $\begin{array}{c}\text { Non-Flaming } \\
\text { Combustion }\end{array}$ & $\begin{array}{l}\text { MOD } \\
\text { Ratio }\end{array}$ \\
\hline Beech & 0.0104 & 0.0580 & 5.58 \\
\hline Oak & 0.0077 & 0.0270 & 3.51 \\
\hline Rhamnus & 0.0108 & 0.0465 & 4.31 \\
\hline Abies & 0.0083 & 0.0300 & 3.61 \\
\hline
\end{tabular}

Table 5: Maximum optical density and Visibility for wood sample

\begin{tabular}{|c|c|c|c|c|}
\hline \multirow{2}{*}{$\begin{array}{l}\text { Type of } \\
\text { wood } \\
\text { sample }\end{array}$} & \multicolumn{2}{|c|}{$\begin{array}{c}\text { Maximum optical } \\
\text { density at } 50 \\
\mathrm{~kW} / \mathrm{m}^{2} \text { heat flux }\end{array}$} & \multicolumn{2}{|c|}{$\begin{array}{l}\text { Maximum } \\
\text { visibility }(\mathrm{m}) \text { at } 50 \\
\mathrm{~kW} / \mathrm{m}^{2} \text { heat flux }\end{array}$} \\
\hline & 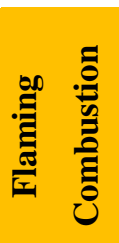 & 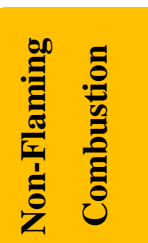 & 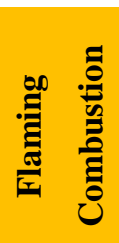 & 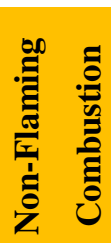 \\
\hline Beech & 140.4 & 707.2 & 0.86 & 0.17 \\
\hline Oak & 53.1 & 217.2 & 2.26 & 0.55 \\
\hline Rhamnus & 49.7 & 191.6 & 2.41 & 0.63 \\
\hline Abies & 28.7 & 106.2 & 4.18 & 1.13 \\
\hline
\end{tabular}

\subsection{Transmittance}

Experiments were conducted to determine the transmittance of wood samples in parallel with the MLR and smoke optical density. The results are presented in terms of transmittance over time for different thermal and flaming conditions, as shown in figures 11, 12 and 13.

Figure 11 shows the transmittance of each sample as a time variation under constant Flaming combustion heat flux of $\left(25 \mathrm{~kW} / \mathrm{m}^{2}\right)$. As the results show, the general trends of transmittance variations decrease by the time with significant quantities for all samples.

This is due to the increased in the concentration of smoke particles, which reduces the spread of light sent to the spectrometer and because of the increase in temperature, which breaks the chemical chains between the sample atoms, resulting in an increase in the burning rate and the amount of smoke produced. It varies from sample to sample depending on the mass burning rate and volumetric flow rate to form smoke in the chamber. In this case, transmittance decreases strongly over time due to low oxygen concentration and high levels of unburned fuel in smoke generated [9].

An insignificant change was happened at the beginning of $(60 \mathrm{~s})$. After that, a considerable change was happened at the next $(60 \mathrm{~s})$ then it decreased rapidly due to the high burning rate to reach its lower values. In (120 s) later, transmittance increases recently due to the formation of a char layer on the surface of wood samples. In this case, the amount of oxygen flowing under the char layer is reduced, which reduces the influence of heat to the decomposing wood, and reduces the apparent heat of gasification. According to Figure 11, Rhamnus, which has the higher values of MLR, has the lower value of transmittance $(68.8 \%)$ compared to other samples. While beech has higher value (91.7\%) reached after (600 seconds).

Figure 12 shows the transmittance of each sample as a time variation under constant Flaming heat flux of $\left(50 \mathrm{~kW} / \mathrm{m}^{2}\right)$. As shown in Figure 12, the transmittance of the samples decreases by the time. It depends, mainly, on the temperature and duration of the interaction with the heat source. However, no sudden changes in transmittance were observed. Initially, the transmittance decreases slowly, and then becomes more significant. The measured reduction value of the beech is $(6.72 \%)$ in 600 seconds with a sudden increase observed between 270 and 420 seconds whereas it is $(70.8 \%)$ for Abies. Figure 12 shows no significant difference in transmission between Oak and Rhamnus. 


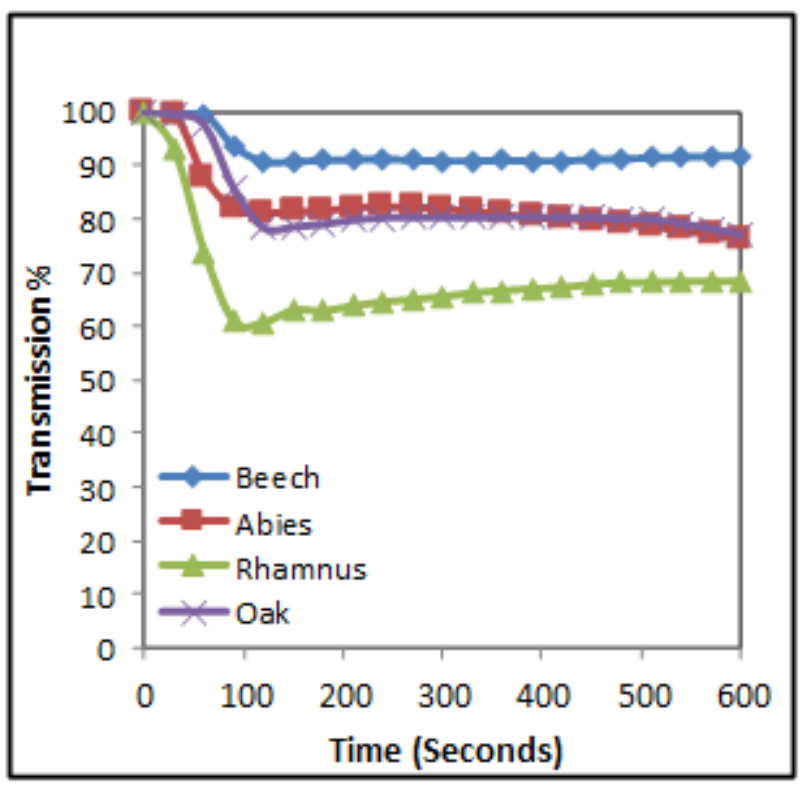

Fig. 11: Temporal variation of transmission of wood samples at Flaming heat flux of $25 \mathrm{~kW} / \mathrm{m}^{2}$.

By comparing these results with those of Figure 11 , doubling the heat flux levels from 25 to 50 $\mathrm{kW} / \mathrm{m}^{2}$ has a significant effect on both transmittance and visibility. The strong relationship between sample transmittance and the incident radiation is clearly observed during the Flaming combustion. As analyzed earlier, at $(120 \mathrm{~s})$, the transmittance of combusted samples increases again to higher values due to the building up of char layer at the wood surface. Beech behaves differently due to the appearance of small cracks in the char layer normal to grain direction. This allows volatile materials to discharge easily through the char layer, which increases the heat in the wood and increases the apparent heat of gasification [4].

During Non-Flaming combustion heat flux of $\left(50 \mathrm{~kW} / \mathrm{m}^{2}\right)$, the smoke produced reduces the transmitted light transferred to the spectrometer. As shown in Figure 13, at the start of test where $(t<30$ $\mathrm{s})$, the transmission is relatively high. After that transmittance decreases strongly over time. With Non-Flaming combustion, it is assumed that the core content of the smoke is in a compressed phase as small droplet suspended in air. This is due to the various dispersion that occurs when the amount of smoke is high since transmittance increases as the wavelength of the violet spectrum decreases [9]. In Figure 13, Non-Flaming heat flux of $\left(50 \mathrm{~kW} / \mathrm{m}^{2}\right)$ has a significant effect on the percentage of transmittance. Its low values are $0.01 \%$ for Beech and $2.25 \%$ for Rhamnus.

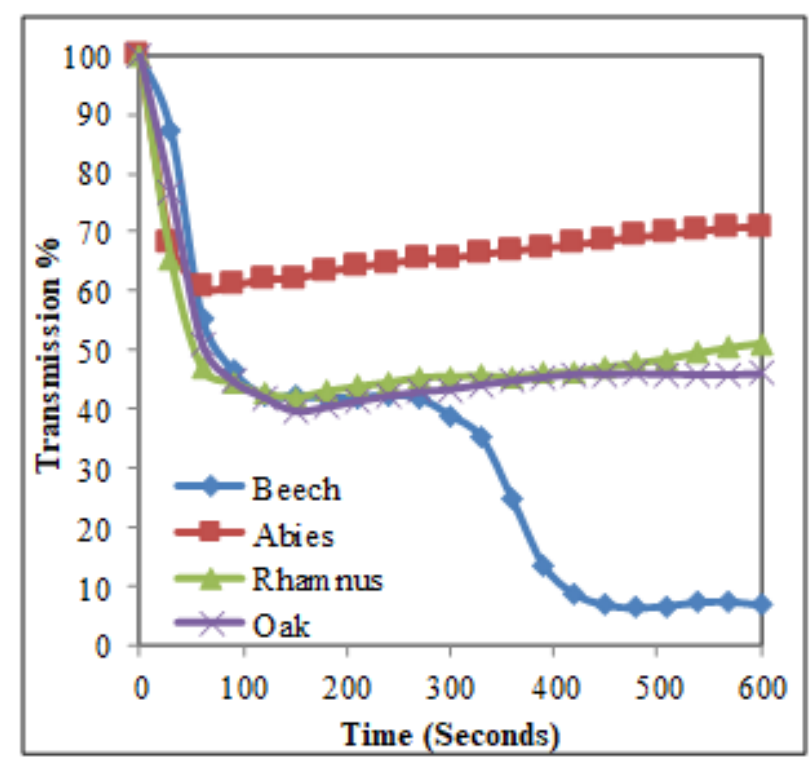

Fig. 12: Temporal variation of transmission of wood samples at Flaming heat flux of $50 \mathrm{~kW} / \mathrm{m}^{2}$.

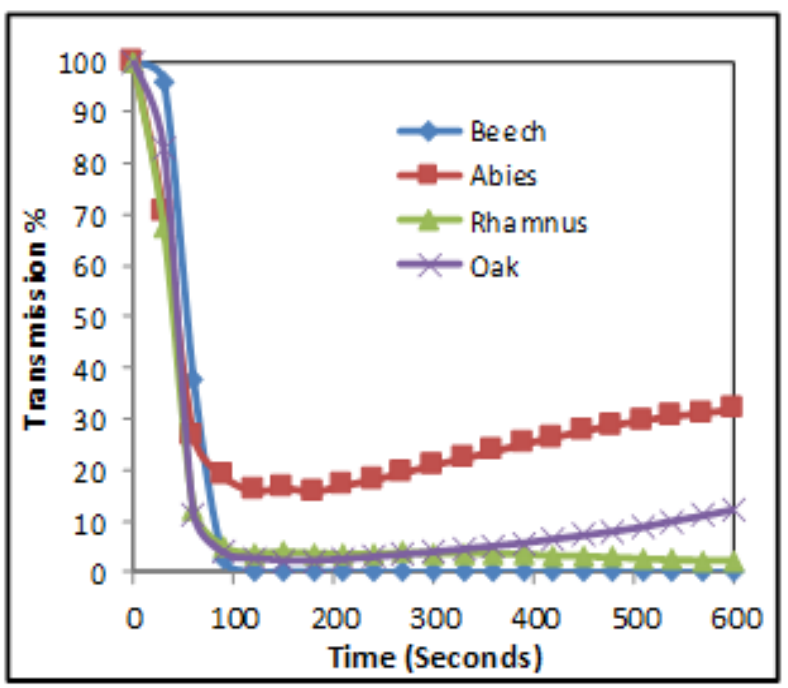

Fig. 13: Temporal variation of transmission of wood samples at Non-Flaming heat flux of $50 \mathrm{~kW} / \mathrm{m}^{2}$

Comparing the results of Figure 13 with those of Figure 12, the results reflect the effect of NonFlaming combustion heat flux on transmittance. Both types of flaming combustions behave with the same trends but with different percentage values as described in Table 6. During Non-Flaming combustion, the samples evolved a high amount of smoke and smoke optical density, resulting in 
reduced transmittance. This is due to the building up of the char layer on the wood surface and the effect of smoldering and limited ventilation. Smoldering occurs due to small cracks that appear in the char. In this case, pyrolysis without ignition, after exposed to an outward heat source, increases the specific optical density and reduces visibility [4].

Table 6: Minimum transmittance for wood samples

\begin{tabular}{|c|c|c|}
$\begin{array}{c}\text { Type of wood } \\
\text { sample }\end{array}$ & \multicolumn{2}{|c|}{$\begin{array}{c}\text { Transmittance \% at } 50 \mathrm{~kW} / \mathrm{m}^{2} \\
\text { heat flux }\end{array}$} \\
\hline & $\begin{array}{c}\text { Flaming } \\
\text { Combustion }\end{array}$ & $\begin{array}{c}\text { Non-Flaming } \\
\text { Combustion }\end{array}$ \\
\hline Beech & 6.72 & 0.01 \\
\hline Oak & 46.0 & 12.2 \\
\hline Rhamnus & 51.1 & 2.25 \\
\hline Abies & 70.8 & 31.8 \\
\hline
\end{tabular}

\section{Conclusions}

In this work, mass loss rate, mass flux, mass optical density, transmittance and specific optical density of wood samples were measured under external heat variation in limited ventilation compartment. An experimental work was carried out in the smoke density chamber. The experimental results demonstrated changes in mass loss rate, specific optical density and transmittances with time for a specified period up to 600 seconds. The samples were exposed to a Flaming combustion of 25 and $50 \mathrm{~kW} / \mathrm{m}^{2}$ and Non-Flaming combustion of $50 \mathrm{~kW} / \mathrm{m}^{2}$ in the horizontal orientation. The following conclusions were reached.

1. The Flaming conditions have no significant effect on the burning rate and mass loss rate when the samples receive the same heat flux while it has a significant effect on both specific optical density and transmittance.

2. MLR \% was seen to increase with heat flux despite varies flaming conditions.

3. Beech has the lower values of specific optical density despite it has the higher values of MLR\% and MOD compared to other samples studied.

4. MOD depends strongly on both radiation heat flux and combustion flaming flaming conditions.

\section{Referances}

[1] Michael H. Ramage, Henry Burridge, Marta Busse-Wicher, George Fereday, Thomas Reynolds, Darshil U. Shah, Guanglu Wu, Li Yu, Patrick Fleming, Danielle Densley-Tingley, Julian Allwood, Paul Dupree, P.F. Linden, Oren Schermam, (2017), The wood from the trees: The use of timber in construction, Renewable and Sustainable Energy Reviews, Vol. 68, Part 1, PP. 333-359.

DOI.org/10.1016/j.rser.2016.09.107

[2] Zarah Walsh-Korb and Luc Averous, (2019), Recent developments in the conservation of materials properties of historical wood, Progress in Materials Science, Vol. 102, PP. 167-221. DOI.org/10.1016/j.pmatsci.2018.12.001

[3] Awad Ahmad, (2019) Experimental Estimation of Fire Characteristics and Heat Release Rate for Jordanian Natural Wood by Means of Oxygen Consumption, International Review of Mechanical Engineering (IREME), Vol. 13, No. 5, Pages 296-304.

DOI.org/10.15866/ireme.v13i5.17064

[4] Drysdale Dougal, (1999), An Introduction to Fire Dynamics, Second Edition. John Wiley \& Sons Ltd, Baffins Lane, Chichester, West Sussex PO191UD, England 1999.

[5] Gao Ran, Fang Zhiyu, Li Angui, Shi Congling, Che Lunfei, (2017), Estimation of building ventilation on the heat release rate of fire in a room, Applied Thermal Engineering. Vol. 121 (2017) PP. 1111-1116.

DOI.org/10.1016/j.applthermaleng.2017.04.048

[6] Alarifi, AAS, Phylaktou, HN and Andrews, GE, (2016), What Kills People in a Fire? Heat or Smoke? In: 9th SSC Proceedings. The 9th Saudi Students Conference, 13-14 Feb 2016, Birmingham, UK. .

https://www.eyeofriyadh.com/news/details/ukconference-highlights-saudi-studentsaccomplishments 
[7] Olimat A, Awad A. and Abu Shaban N. (2020), Experimental Investigation on the Effect of Fire-Resistant Coatings on Combustion and Flame Spread Characteristics by Medium Density, International Review of Mechanical Engineering (IREME), Vol. 14, No. 1, Pages 917.

DOI.org/10.15866/ireme.v14i1.18498

[8] Carosio F. Cuttica L. Medin L. A. Berglunda, (2016), Clay nanopaper as multifunctional brick and mortar fire protection coating-Wood case study, Materials and Design, Vol. 93, PP. 357363.

DOI.org/10.1016/j.matdes.2015.12.140

[9] Olimat A., Awad A., Al-Ghathian F. (2017), Effect of Fire Retardant Painting Product on Specific optical density of Burning Natural Wood Samples, Conference Proceeding, London, United Kingdom, September 21-22/ 2017.

DOI.org/10.5281/zenodo.1340364

[10] Abdul-Reheem Faiez F, (1985), Quantification of Smoke Produce In Fires, University of Edinburgh, Thesis (Ph.D), oai:www.era.lib.ed.ac.uk:1842/11342.

[11] Purser, D.A, (1995). 'Toxicity assessment of combustion products', in SFPE Handbook of Fire Protection Engineering, National Fire Protection Association, Quincy, Massachusetts, $2^{\text {nd }}$ ed., Chapters 2-8.

[12] Aneesh Prabhakar, Nilesh Agrawal, Vasudevan Raghavan, Sarit K. Das, (2016), Experimental investigation on helium distribution and stratification in unventilated vertical cylindrical enclosure - Effect of jet release rates and total release volume, International Journal of Hydrogen Energy, Volume 41, Issue 48, Pages 23213-23228.

DOI.org/10.1016/j.ijhydene.2016.10.098

[13] Benjamin panelIrwin A., (1984), The challenge of smoke, Fire Safety Journal, Vol. 7, No. 1, PP. 3-9.

DOI.org/10.1016/0379-7112(84)90003-1
[14] Rasbash, D. J., (1967), Smoke and Toxic Products at Fires, Trans, J. Plastics Inst., p. 55, (Jan. 1967)

[15] Yunyong Utiskul, James G. Quintiere, Ali S. Rangwala, Brian A. Ringwelski, Tomohiro Naruse, (2005), Compartment fire phenomena under limited ventilation, Fire Safety Journal, Volume 40, Issue 4, Pages 367-390 DOI.org/10.1016/j.firesaf.2005.02.002

[16] Zhai Chunjie, Gong Junhui, Zhou Xiaodong, Peng Fei, Yang Lizhong, (2017), Pyrolysis and spontaneous ignition of wood under timedependent heat flux, Journal of Analytical and Applied Pyrolysis, Vol. 125, May 2017, PP. 100-108.

DOI.org/10.1016/j.jaap.2017.04.013

[17] Thomas Jan C., Hadden Rory M., Simeoni Albert, (2017), Experimental investigation of the impact of oxygen flux on the burning dynamics of forest fuel beds, Fire Safety Journal, Vol. 91, PP. 855-863.

DOI.org/10.1016/j.firesaf.2017.03.086

[18] Quintiere, J.G. (1995). 'Compartment fire modelling', in the SFPE Handbook of Fire Protection Engineering, $2^{\text {nd }}$ ed, Fire Protection Association, Quincy, MA, 1995.

[19] Ostman A. L. and Tsantaridis L. D. (1991), smoke production in the cone calorimeter and the room fire test, Fire Safety Journal, Vol. 17, No. 1, PP. 27-43.

DOI.org/10.1016/0379-7112(91)90011-M

[20] Butcher, E. G. and Parnell, A. C., (1979), "Smoke control in fire safety design", Published by: London [England]: Spon, 1979, London. United Kingdom. ISBN: 0419111905. https://trove.nla.gov.au/work/10221440?q\&ver sionId $=45248074$

[21] Lee T. G. (1973), The smoke density chamber method for evaluation the potential smoke generation of building materials", NBS Technical notes 757, U.S. Department of commerce, national bureau of standards. https://www.amazon.com/EvaluatingPotential-Generation-MaterialsTechnical/dp/B000IU71UY 
[22] Yang H, Yan R, Chen H, Zheng C, Lee D, Liang DT (2006), In-depth investigation of biomass pyrolysis based on three major components: hemicellulose, cellulose and lignin. Energy Fuels, Vol. 20, PP. 388-393.

DOI.org/10.1021/ef0580117

[23] Kučerová Viera, Lagaňa Rastislav and Hýrošová Tatiana, (2019), Changes in chemical and optical properties of silver fir (Abies alba L.) wood due to thermal treatment, Journal of Wood Science vol. 65, Article number: 21.

DOI: $10.1186 / \mathrm{s} 10086-019-1800-\mathrm{x}$

[24] Terrei Lucas, Acem Zoubir, Georges Véronique, Lardet Paul, Parent Gilles, (2019), Experimental tools applied to ignition study of spruce wood under cone calorimeter, Fire Safety Journal, Vol. 108, Article 102845. DOI.org/10.1016/j.firesaf.2019.102845

[25] Węgrzyński Wojciech and Vigne Gabriele , Experimental and numerical evaluation of the influence of the soot yield on the visibility in smoke in CFD analysis, (2017), Fire Safety Journal, Vol. 91, Pages 389-398

DOI: 10.1016/j.firesaf.2017.03.053

\section{Creative Commons Attribution License}

\section{0 (Attribution 4.0}

\section{International, CC BY 4.0)}

This article is published under the terms of the

Creative Commons Attribution License 4.0

https://creativecommons.org/licenses/by/4.0/deed.en $\% 20$ US 